\title{
Analyzing contrastive features in English and Persian argumentative writing
}

Kamyabi Gol, Atiyeh $\triangle$

Department of Linguistics, Ferdowsi University of Mashhad, Iran (kamyabigol@um.ac.ir)

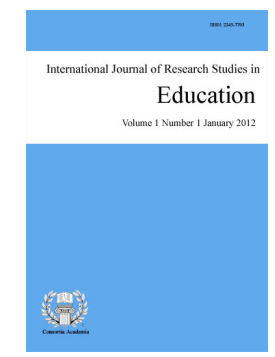

ISSN: $2243-7703$ Online ISSN: 2243-7711

OPEN ACCESS

\section{Abstract}

Having the ability to write effectively is important to both achieve and also to demonstrate academic success. With the growing number of Iranian students studying overseas, it is necessary to see whether the Persian rhetorical culture influences students' English writing. In this study, the researcher aimed to investigate the style differences between English and Persian writing and the possibility of transfer. A total of 65 university students took part in the study. Data was collected through two argumentative writing tasks and a 15-20 minute interview. A total of 130 argumentative essays (65 Persian and 65 English) were analyzed according to the five contrastive features framework provided by Xing, Wang, and Spencer (2008). Inter-rater reliability was used in order to enhance the precision in essay correction. The results show that there is a great possibility of transfer from the participants' L1 into L2 in the areas of number of topic sentences per paragraph, and also figurative language usage. Traces of backward transfer were also detected in inductive/deductive use of thesis statement in writing. Practical implications for teachers, professors and also students have been provided at the end of the paper.

Keywords: contrastive features; contrastive rhetoric styles; argumentative essays; English and Persian rhetorical styles 


\section{Analyzing contrastive features in English and Persian argumentative writing}

\section{Introduction}

In the postmodern world we are living in today, effective communication is becoming a vital skill for individuals. One means of achieving this goal is through effective writing. According to Liu and You (2008) effective English writing is a rudimentary tool for both academic and a professional career. Leki and Carson (1994) assert that being able to write well is a must in both achieving and demonstrating one's academic proficiency. According to Raimes (1983), achieving proficiency in writing can only be attained through successfully dealing with "content, audience, purpose, word choice, organization, mechanics, syntax and grammar" (P. 6). Mastering any one of these areas takes years of practice and a lot of hard work. Students persevere to achieve proficiency from elementary schools. This goal becomes even more daunting to achieve for students writing in a language that is not their mother tongue. Many scholars (Buckingham, 2008; Siepmann, 2006; Gosden, 1996; Jalilifar, 2008, Rooholamini, 1986; Victori, 1999; Schneider \& Fujishima 1995; and Samiee, 2008) believe that writing is the most difficult skill to acquire and that culture and cultural backgrounds play a vital role in how an individual writes.

Although students might have a logical orientation while writing, their writing might be considered illogical by the instructor due to the cultural differences between the two (Xing, Wang, \& Spencer, 2008). In fact, cultural difference is the main source of difficulty for English as second language writers, but as Fox (2003) puts it: "lack of understanding and lack of intelligence are not necessarily related" (p. 5). Connor (1996) believes that "contrastive rhetoricians maintain that different reader expectations are the primary reason for cross-cultural differences in writing styles and that students should be made aware of these differences by their teachers" ( $p$. 167).

By considering the fact that writing in one's mother tongue is probably the most difficult skill to acquire, it becomes apparent why foreign language writing becomes such a daunting task for foreign language students. Jalilifar (2008) confirms this claim and asserts that "writing in a second language is further complicated by issues of proficiency in the target language, first language literacy, and differences in culture and rhetorical approach to the text" (p. 114). If culture does in fact influence writing, then this might be a reason why non-native speakers' writings are sometimes labeled as disorganized, digressive, drifting, waffling, vague, indirect, incoherent, irrelevant, and loosely structured (Lux, 1991; Ballard \& Clanchy, 1991; Cortazzi \& Jin 1997; Saneh, 2009). For example, in Persian composition classes, students are always encouraged to use proverbs and quote many famous scholars in their writings; however, these are considered a cliché or lacking in originality (Wong, 1992; Robitaille \& Connelly, 2007) in English writing and receive negative scoring.

\section{Review of Literature}

\subsection{Kaplan and Contrastive Rhetoric}

Kaplan is the father of contrastive rhetoric. In his study of approximately 600 EFL student compositions, Kaplan (1966) was able to come up with a number of patterns that the language groups he was studying were applying. Kaplan analyzed the compositions of students with various language backgrounds including: Arabic, Chinese, French, Spanish, and Russian. In his work, Kaplan used psychological, philosophical, linguistic and anthropological insights to analyze the differences between English and the language groups he had selected (Reid, 1988). These EFL students came from three basic language groups which included Semitic, Oriental, and Romance. After Kaplan's analysis of these EFL students' compositions, he found that these groups of writers preferred various strategies regarding paragraph development. Semitic writers favored "parallelism", Orientals 
Analyzing contrastive features in English and Persian argumentative writing

had a tendency toward "Circular" and the Romance group used a "Digressive" mode of paragraph organization.

Kaplan believes that students from various cultural backgrounds write according to different rhetorical patterns. He divides these patterns into Oriental, Semitic, Romance, Russian, and English. In his article which was later known as "doodles", Kaplan, showed the possible paths of movement by the following graphics (figure $1)$ :

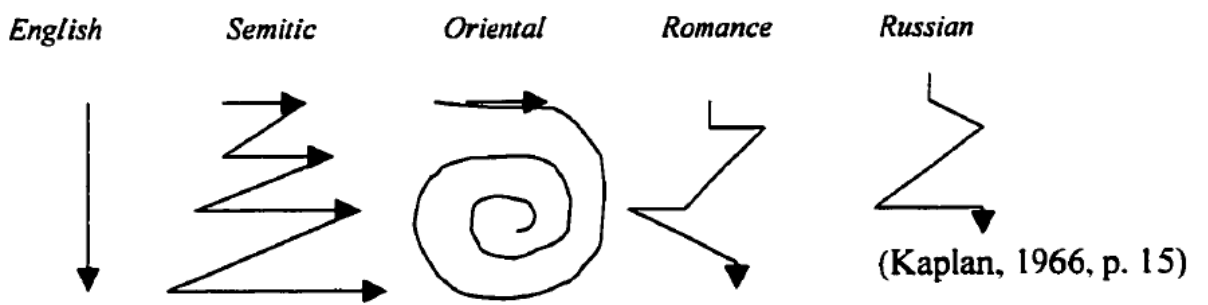

Figure 1: Kaplan's graphics showing the possible paths of movement in writing (Adopted from Kaplan, 1966 , p. 15)

According to Kaplan (1966), it is necessary for ESL/EFL students to identify their native language shape of a paragraph and compare that with the ideal English version. Kaplan asserts "a student has to learn the form within which he may operate a form acceptable in this time and in this place" (p. 20).

\subsection{New Contrastive Rhetoric and Studies Surrounding the Issue}

Over the past two decades, Kaplan together with Connor and Purves has tried to clarify some confusing parts of the earlier contrastive rhetoric theory and together, they tried to define a new contrastive rhetoric theory in the means. The main source of difference between the earlier and the new version of contrastive rhetoric theory lies in the fact that while the earlier version was based on linguistic deficiencies, the new version concentrates on cognitive deficiencies. So there is a shift from a linguistic framework to a more sociocultural one. In the new version, the differences between cultures are taken into account more than before.

In 1990, Hinds analyzed a number of texts written by some Asian groups including Chinese, Japanese, Korean and Thai. He focused on the place of the thesis statement (inductive vs. deductive) in the text. He found out that, surprisingly, these participants' writings did not follow either the inductive or the deductive organization pattern. Therefore, Hinds believes these Asian groups writings are what he calls quasi inductive.

In 1995, Kirkpatrick studied the inductive/deductive preference of Chinese. He found that although the Chinese are capable of reasoning deductively, they still prefer inductive argument. He reports that the deductive style of reasoning is most often used for a special purpose, more often than not, for portraying directness. Kirkpatrick also point to the importance of hierarchical relationship at the family and political level. He then writes that argument and persuasion "has often been conducted by an inferior to a superior, or bottom up. This has encouraged the adoption of a method of expression and argument that is indirect" (p. 291). He believes it is for his reason that the Chinese preferred style of argument is inductive.

Fakhri (2004) studied some Arabic research articles and found that although Arabic is generally a reader responsible type of writing, it is not always the case and that there are always some exceptions to this. He also found that some articles show a high degree of directness while some articles do not. While, in 2007, Zarei and Mansoori compared English and Persian research articles and found that while English represents a more writer oriented style, Persian -like many Asian languages such as Chinese and Japanese- is reader responsible and so the reader has to play an active role in understanding what the writer has meant to say.

In Liu and You's study (2008), they found that the rhetorical traditions of both the American and Taiwanese students influenced the way they wrote in English. The Taiwanese students emphasized on showing their knowledge in their research writing while the Americans sought to bring in evidence for their ideas by means of 
Kamyabi Gol, A.

direct quotes. Donahue (2008) studied the differences between French students' essays written in English and American students' essays and found that while French students tended to use pronouns such as "one" or "we", the Americans used "I". She also found that while in $84 \%$ of the American essays, the thesis was established from the start the French essays did not follow the same style.

Baleghizadeh and pashaii (2010) conducted a contrastive study on the rhetorical organization of essays written by native English and Iranian students. They studied 25 Persian and 25 English essays for the frequency of T-units, discourse blocs, and coordinating conjunctions. The results of their quantitative study showed that the Iranian students Used all three features more than their English counterparts. Baleghizadeh and pashaii (2010) asserted that this was the result of the differences in the thought patterns of Iranian and English writers. Abdollahzadeh (2010) interviewed some freshman and senior Iranian students and asked them about the various strategies they used while writing in English. He found out that the two groups used different cognitive strategies. The main difference between the two groups was that while the less advanced freshman used translation as the main cognitive strategy, the more advanced students utilized outlining and planning for their writings.

\subsection{Persian Language and Rhetoric History}

The Persian language is a part of the Indo-Iranian language group which is a member of a larger group known as Indo-European language (Daniel, 2000; Dehghani, 2007). The word "Persian" has been used for more than 500 years in the English language. It has been used to describe not only the language, but also a nation which has a 7000 year archaeological history. The Persian language has been spoken since the time of the Achaemenides (Dastmalchian, Javidan, \& Alam, 2001). The Persian script has been changed many times throughout the centuries. The Persian script was initially written from left to right but with the dawn of Islam in Iran in $670 \mathrm{AD}$, the Arabic script came to the limelight and so from this point on Persian has been written from right to left (Dastmalchian, Javidan, \& Alam, 2001; Daniel, 2000; Dehghani, 2007). Of course, it should be kept in mind that Persian added four characters (sounds) to its alphabet which do not exist in the Arabic language (/p/, $/ \check{c} /, / g /, / \check{z} /)$. Linguistically speaking, English is not a very difficult language to acquire by Persian speakers (Strain, 1971). However, the English alphabet and spelling system is a completely different story.

While the Persian language has not received a lot of attention in regard to contrastive studies and as Reid (1988) also asserts that some languages including Persian "have not yet been carefully scrutinized" (p. 28), it is worth mentioning that Persian is also one the foreign languages that appreciates the use of proverbs and quotes in compositions. As Dehghanpisheh (1979) states "expository topics in Persian are often developed by such literary devices as proverbs and metaphors" (p. 511). She also found out that students tend to carry this into their English writing. As Reid (1984) posits: "an expository paper by a Farsi writer may elicit such questions as what has this information to do with the topic? Why does he include so much irrelevant material?" (p. 449). Furthermore, Saneh (2009) interviewed some Iranian postgraduate students studying in U.S.A. and when she asked about these students' experiences with the Iranian educational system regarding writing, this is what she heard from the interviewees:

Composition topics were always the same, it wasn't really about creativity for the most part. And you never knew the teachers' criteria for making. For them the only good writing was beautiful writing... they kept saying "so and so writes beautifully" but we never got any instruction, they just told us start with an introduction and then talk about your topic and finally wrap it up with a conclusion of some sort. Of course the introduction could be a religious cliché, like starting in the name of God, or a line of poetry for opening...it wasn't really important if it was relevant to the topic or not, just something to take it from there and gradually get into the topic. That's all they ever told you (p. 84).

It is interesting that Saneh (2009) and even the present researcher has had a similar experience with the Iranian educational system. 
Analyzing contrastive features in English and Persian argumentative writing

Many Persian writing manuals (Derakhshan, 1988; Ghorbaniun, 2004; Taherkhani, 1995; Samiee, 2008) insist on the use of literary language and quotes to enrich the writing. However, they never mention how far the students can go. In fact, one strategy many students are taught in composition classes in order to write more effective compositions is the same use of literary language. Persian is not the only language that favors such flowery language in compositions. Many languages including Spanish, Chinese, Indian, and Arabic also use a great deal of figurative language in their writing. The Spanish style of writing tends to be more elaborative regarding the use of metaphors, similes, and an overall more poetic and flowery style of writing (Phung, 2006). According to Montano-Harmon (1991) this poetic and flowery language actually contributes in making Spanish texts more complex than English ones. As Snively (1999) puts it: "the Chinese rely greatly on quotations, analogies, aphorisms, metaphors, similes, and rhetorical questions" (p. 31).

\subsection{The Five Contrastive Features Framework}

In 2008, Xing, Wang, and Spencer collected 5 contrastive features found by a number of scholars in previous studies. These studies include: Ballard and Clanchy (1991); Cho (1999); Connor (1996); Cortazzi and Jin (1997); Schneider and Fujishima (1995). Xing, Wang, and Spencer (2008) used these 5 contrastive features to come up with a comprehensive framework for analyzing writing styles. They used the 5 contrastive features to compare British English and Chinese writing styles. Their 5 contrastive features include:

Inductive vs. Deductive: This feature refers to the position of the thesis statement in the essay. A thesis statement is defined as a sentence summarizing the fundamental argument of any essay. According to Xing, Wang, and Spencer (2008) If the thesis statement is placed at the beginning of the introduction or at most in the first paragraph of the written essay, the essay is assumed to be deductive, and if background information is given first then followed by the main point, it might be inductive.

$>$ Start-Sustain-Turn-Sum vs. Introduction-Body-Conclusion: This feature mentions the overall rhetorical style used in the written essay. It is believed that the Chinese rhetorical style consists of four sections (Kirkpatrick, 1995). Xing, Wang, and Spencer (2008) explain about these four sections qi ('start, open') establishes the field or prepares the reader for the topic; cheng ('carry on, sustain') introduces and develops the topic; zhuan ('turn') turns to a seemingly unrelated subject or looks at the problem from another angle; and he ('conclude') sums up the essay whereby the author's opinion is established or hinted at (p. 74). The English (American and British) way of structuring an essay usually includes an introduction, a body and a conclusion.

$>$ Circular vs. Linear: This third feature pertains to the number of topic sentences mentioned per paragraph. In order to have a systematic definition Xing, Wang, and Spencer (2008) elucidate that Circularity can be measured by looking at the frequency of topic changes in paragraphs where topic sentences are used. Linearity can be indicated by a low frequency of topic changes or a low average number of topic sentences in a paragraph (p. 74).

$>$ Metaphorical vs. Straightforward: This feature directs our attention to the use of metaphors and proverbs in a written essay. The use of metaphors, allusions, similes, analogies, proverbs, etc.

$>$ Explicit Discourse Markers: The last feature in the 5 contrastive features refers to the number and type of discourse markers. The use of explicit discourse markers adds to the unity and overall coherence of the written essay. The number and kind of discourse markers used can show the rhetorical differences that might exist between two languages. However, it must be mentioned that Xing, Wang, and Spencer (2008) do not mention what framework they have used in their study. It is with this in mind that the researcher decided to use Fraser's taxonomy of discourse markers in order to make the methodology more systematic. 


\subsection{Fraser's Taxonomy of Discourse Markers}

For the present study, the researcher decided to use Fraser's (1999) taxonomy of discourse markers. This taxonomy was selected because "it conforms to written discourse and that it seems to be the most comprehensive classification in written discourse" (Jalilifar, 2008, p. 115). This taxonomy is made up of three main subclasses including:

Contrastive markers that signal "the explicit interpretation of the second sentence contrasts with an interpretation of the first sentence" e.g. although, but, despite, ... (Jalilifar, 2008, p. 115).

Elaborative markers that signal "a quasi-parallel relationship between the sentences" e.g. and, above all, also,... (Fraser, 1999, p. 948).

Inferential markers that signal "the following sentence is a conclusion derived from the preceding sentence" e.g. accordingly, so, then,... (Fraser, 1999, p. 948).

By considering the fact that the number of Iranian students studying overseas is growing each year, it is essential to check whether the Persian rhetorical culture can influence students' English writing and how significant is this transfer to English writing? Research suggests that writers tend to use the rhetorical patterns of their first language when they are writing in a second language. Many studies have considered the transfer from various languages such as Chinese, Japanese, German, French, and Turkish to English (Hafernik, 1990; Xing, Wang, \& Spencer, 2008; Siepmann, 2006; Kobayashi, \& Rinnert, 2008; Buckingham, 2008). However, the possibility and extent of transfer from Persian to English has not received its due attention (Izadi Agha, 2007).

In this study the researcher aims to investigate the style differences between English and Persian writing and to determine whether participating Iranian EFL students transfer Persian writing cultural norms to their English argumentative writings.

\subsection{Research Questions}

The following research questions were utilized in conducting the present study:

$>\quad$ What are the style differences in writing (according to the five contrastive features) between Persian and English?

$>\quad$ What contrastive features (according to the five contrastive features) do the Iranian EFL students transfer from Persian to English writing?

\section{Material and Methods}

To testify the truth or falsity of the research hypotheses, data collection and analysis were first conducted. The following section provides information on sampling, instrumentation, and finally procedure which was used in the study.

\subsection{Participants}

65 Advanced Iranian EFL students (both males and females) were asked to write two argumentative essays. The participants were selected from a private university in Mashhad, Iran. The 65 student participants were all Bachelor university students. They were majoring in foreign languages, social sciences, basic sciences, engineering, and art. Their ages ranged from 20 to 36. Overall, 25 males and 40 females took part in this section. Age and gender did not play a role in the present study. All the participants had studied English for at least 4 years. This was crucial in order to ensure the participants' English command in order to make good judgment regarding their English writing problems. These students were at an advanced level of proficiency in English 
based on a TOEFL PBT exam.

\subsection{Argumentative Writing Task}

In order to ensure the students' precision in writing the argumentative essays, the researcher approached a number of EFL professors who were teaching English at the private university. This was done in order to use the professor's authority in class to ensure students' precession in writing. After getting their cooperation, the teachers assigned the writing tasks as class activity for the students.

A total of 65 Advanced EFL students were asked to write a 400 word Persian argumentative essay. Participants were asked to write an essay arguing Iran's right to nuclear power. The students were asked to type the essays and E-mail them to an E-mail account created by the researcher. After a three week time lapse, similar instructions were given to students; the only difference was that they were asked to write in English with the same topic this time round. There was no time restriction as many scholars (Kobayashi \& Rinnert, 2008; Zia Houseini \& Derakhshan, 2006; Raimes, 1983) believe time restriction can hinder the true performance of students. Argumentative essay was chosen, because "it is common in the academic disciplines and it is sensitive to task, audience and community, and it is particularly difficult for non-native speaker" (Johns, 1993, p. 76).

\subsection{Interview}

In order to triangulate the participants' responses, the researcher conducted an interview along with the students' written essays. The interviews were mainly used as a secondary source of information which was used more as "a medium for guided reflections" (Buckingham, 2008, p. 5).

The interview questions aimed at uncovering how the respondents plan and write in English and what they transfer from Persian writing styles. The aim of conducting such an interview was to understand the participants' perspectives regarding their essay writing and their writing background. The interview questions were based on Gosden (1996); Victori (1999); and Buckingham (2008). The interview was conducted in English as the participants had a good command over English. The interview was limited to 15-20 minutes. The 30 participants for this section included 15 male and 15 female students. This was done to ensure both genders had an equal chance at expressing their views.

\section{Results and Discussion}

This section provides us with a report and a discussion regarding the research findings in response to the research question. The overall pool of data for the present study was provided through the obtained information through the written argumentative essays and interviews. Overall, a total of 130 argumentative essays (65 Persian and 65 English) were written.

\subsection{Inter Rater Reliability}

In order to be objective in presenting the results of the study, it was essential that more than one rater analyze the essays (Connor, 1996). Both raters were bilinguals and had been teaching writing courses for more than 10 years. One statistical measurement for inter rater reliability is Cohen's Kappa and this was calculated. According to this categorization, the overall inter rater reliability (0.89) shows that the agreement between the two raters was "almost perfect" in this study.

\subsection{Comparison and Contrast between Participants' English and Persian Argumentative Essays}

In this section, the Advanced Iranian EFL students' English and Persian argumentative essays are compared with regards to the 5 contrastive features framework. 


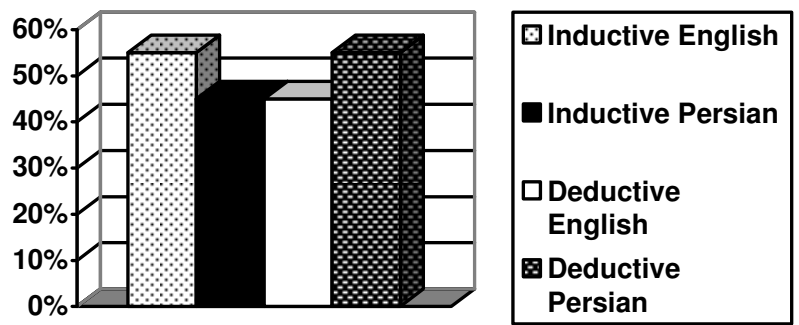

Figure 2. Percentage of Inductive Vs. Deductive in English and Persian

As can be seen in Figure 2., while in the English argumentative essays the EFL students opted for an inductive feature $(55 \%)$, their Persian argumentative essays more deductive (55\%). Although the students are indirectly encouraged to write more in the English preferred style of deductive structure, they seem to pay more attention to this fact while writing their Persian argumentative essays.

One reason for the present result obtained might come from the fact that students are more comfortable writing in their mother tongue and so they might find it easier to take a stand in Persian writing than in English. When asked about how they planned their writing in English, Interviewee 7 had this to say: "At first because of my mother tongue, I like to write in Persian". This comment shows that he pays more attention to Persian even when planning for an English essay.

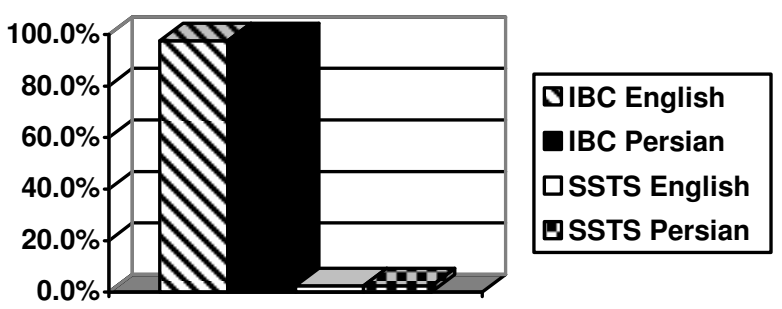

Figure 3. Percentage of IBC Vs. SSTS in English and Persian

The results in Figure 3 show the same situation for both English and Persian argumentative essays. Most Advanced Iranian EFL students (97.5\%) preferred to use the introduction-body-conclusion style of writing as opposed to the start-sustain-turn-sum style. They generally focused on the topic they were writing about and did not stray from it. This was the same case in both languages. It is interesting to point out that S-S-T-S structure was only used by one student in his writing and it was this same student who used this structure in both his written essays.
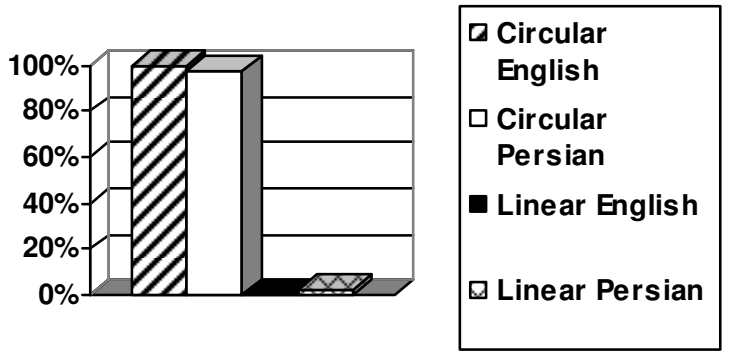

Figure 4. Percentage of Circular Vs. Linear in English and Persian

It is apparent from Figure 4 that the Advanced Iranian EFL students preferred a circular style of writing in 
Analyzing contrastive features in English and Persian argumentative writing

both their English and Persian argumentative essays. This means that the Advanced Iranian EFL students had a high frequency of topic changes within a paragraph which in turn adds up to a less comprehensive essay from the readers' perspective (Xing, Wang, \& Spencer; 2008).

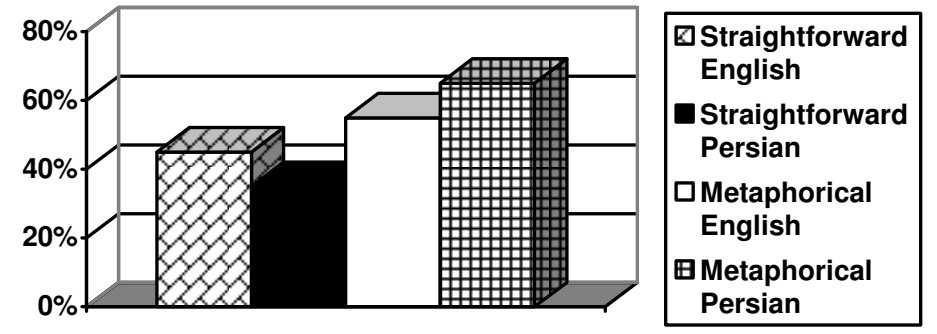

Figure 5. Percentage of Straightforward Vs. Metaphorical in English and Persian

The use of metaphors, allusions, imageries, proverbs, idioms etc. is thought to contribute to the overall beauty of the written text in Persian (Dehghanpisheh, 1979; Reid, 1984; and Saneh, 2009). However, these literary patterns are mostly considered clichés in the western readers' eyes. The findings from this study are in line with what has been indicated by the above scholars; the results from figure 5., clearly show the preference of the Advanced Iranian EFL students in applying a metaphorical style to their argumentative writing in both English and Persian. It is noteworthy to mention that the Advanced Iranian EFL students used $10 \%$ more metaphorical elements in their Persian essays as compared to their English essays.

Most of the transfers that were found during the analysis of the Advanced Iranian EFL students' argumentative essays included vocabulary, prepositions and expression from Persian to English. Therefore a table was created for each of these features with some extracts from the essays. Table 1 consists of the Persian vocabulary items which have been transferred to English by the participants. Again, the translations were all checked with the second rater in order to establish a better translation.

\section{Table 1}

Sample of vocabulary items transferred from Persian to English essays

\begin{tabular}{|c|c|c|c|c|}
\hline $\begin{array}{l}\text { Essay } \\
\text { Number }\end{array}$ & $\begin{array}{c}\text { Persian Vocabulary } \\
\text { (extract from Persian essays) }\end{array}$ & $\begin{array}{c}\text { Vocabulary Translated } \\
\text { (not mentioned in Persian essays) }\end{array}$ & $\begin{array}{c}\text { Vocabulary Used } \\
\text { (transferred to English) }\end{array}$ & Vocabulary Meant \\
\hline 5 & Not mentioned in Persian essay & تحصيلات عاليه & $\begin{array}{l}\text { Elementary school is the basis of } \\
\text { complete educations }\end{array}$ & Higher education \\
\hline 10 & Not mentioned in Persian essay & شر ايط & $\begin{array}{l}\text { Coeducational physical education } \\
\text { classes revealed quite different } \\
\text { climates }\end{array}$ & Condition \\
\hline 11 & Not mentioned in Persian essay & روبرو شدن & $\begin{array}{l}\text { We still face some university } \\
\text { students who have some } \\
\text { problems in communicating with } \\
\text { the other gender }\end{array}$ & $\begin{array}{c}\text { Encounter, come across, } \\
\text { meet }\end{array}$ \\
\hline 12 & كار هاى خار ج از برنامه & -- & Out of classes work & Extra-curricular activity \\
\hline 14 & Not mentioned in Persian essay & سطوح مختلف زندكى & $\begin{array}{l}\text { People are living in different } \\
\text { levels of life }\end{array}$ & Walks \\
\hline 18 & بِر ها بهتر است نمر ات دختر ها از & -- & Girls degrees are better than boys & Scores \\
\hline 20 & Not mentioned in Persian essay & نمر ات خيلى بالا & Very top grades & Very high scores \\
\hline 23 & Not mentioned in Persian essay & فعاليت هاى بدنى & Bodily activities & Physical activity \\
\hline 34 & Not mentioned in Persian essay & بدست آوردن & $\begin{array}{l}\text { That may help girls to earn } \\
\text { important experiences }\end{array}$ & gain \\
\hline 40 & محبطى آر ام & -- & Peaceful space & Environment \\
\hline
\end{tabular}

As can be seen from the above table, the italicized bolded vocabulary items have been translated from Persian into English. Bhela (1999) also found vocabulary and prepositions to be two of the most important groups to be transferred from the students' L1 (Spanish, Vietnamese, Cambodian, Italian) into English. Bhela (1999) believes the participants' first language can directly interfere with the acquisition of second language writing. While, Table 2 takes into account the prepositions that have been transferred from Persian to English. 
Kamyabi Gol, A.

Table 2

Sample of preposition items transferred from Persian to English essays

\begin{tabular}{|c|c|c|c|c|}
\hline $\begin{array}{l}\text { Essay } \\
\text { Number }\end{array}$ & $\begin{array}{c}\text { Persian Preposition (extract } \\
\text { from } \\
\text { Persian essays) } \\
\end{array}$ & $\begin{array}{c}\text { Preposition Translated } \\
\text { (not mentioned in Persian } \\
\text { essays) }\end{array}$ & $\begin{array}{c}\text { Preposition Used } \\
\text { (transferred to English) }\end{array}$ & Preposition Meant \\
\hline 2 & $\begin{array}{c}\text { Not mentioned in Persian } \\
\text { essay }\end{array}$ & در & In all over the world & No In needed in English \\
\hline 7 & $\begin{array}{c}\text { Not mentioned in Persian } \\
\text { essay }\end{array}$ & با & Encounters to others & with \\
\hline 13 & $\begin{array}{c}\text { Not mentioned in Persian } \\
\text { essay }\end{array}$ & از & In the other hand & On \\
\hline 22 & به به & -- & $\begin{array}{c}\text { Don't need to two separate } \\
\text { school }\end{array}$ & No to needed in English \\
\hline 25 & $\begin{array}{c}\text { Not mentioned in Persian } \\
\text { essay }\end{array}$ & به & $\begin{array}{c}\text { The first step for entering in } \\
\text { society }\end{array}$ & No in needed in English \\
\hline
\end{tabular}

As can be observed from the above table, most prepositional errors occur when the students add prepositions which are not needed in English. They use the prepositions from Persian and directly transfer them to their English argumentative essays. Izadi Agha (2007) found that Iranian students have a great difficulty applying the correct preposition in English. She believed the reason for this to be the extensive number and the variety of prepositions in English as compared to Persian. She asserts that "For every two or three prepositions in English, there usually exists only one counterpart in Persian" (p. 105). Therefore, the Iranian students just tend to use that one preposition to represent the various counterparts in English. Finally, in Table 3 the Persian expressions translated into English can be observed.

Table 3

Sample of expression items transferred from Persian to English essays

\begin{tabular}{|c|c|c|c|c|}
\hline Essay Number(s) & $\begin{array}{c}\text { Persian Expression (extract } \\
\text { from } \\
\text { Persian essays) } \\
\end{array}$ & $\begin{array}{c}\text { Expression Translated } \\
\text { (not mentioned in Persian } \\
\text { essays) }\end{array}$ & $\begin{array}{c}\text { Expression Used } \\
\text { (transferred to English) }\end{array}$ & Expression Meaning \\
\hline 1,26 & مدرسه به عنو ان خانه دوم & -- & School is their second home & $\begin{array}{l}\text { Referring to the importance } \\
\text { of school }\end{array}$ \\
\hline 4,8 & $\begin{array}{c}\text { Not mentioned in Persian } \\
\text { essay }\end{array}$ & هر سكه دو رو دارد & Each coin has two faces & Each coin has two sides \\
\hline $6,21,24,25,29$ & بسر ها شير و دختر ها موش بودن & -- & $\begin{array}{l}\text { boys would not be lions and } \\
\text { the girls become mouse }\end{array}$ & $\begin{array}{l}\text { Shows the strength and } \\
\text { boldness of boys as opposed } \\
\text { to girls }\end{array}$ \\
\hline 12 & به قولى حيا & -- & Where is the Haya of the cat & $\begin{array}{l}\text { Emphasizes the integrity of } \\
\text { humans. }\end{array}$ \\
\hline 14,17 & خشت اول كَر نهد معمار كج، تا ثريا & -- & $\begin{array}{l}\text { If the first brick architect is } \\
\text { tilt, tilted wall goes up } \\
\text { Soraya }\end{array}$ & $\begin{array}{l}\text { Generally means a good } \\
\text { beginning makes a good } \\
\text { ending }\end{array}$ \\
\hline 18 & $\begin{array}{c}\text { Not mentioned in Persian } \\
\text { essay }\end{array}$ & دخى دا خجالتشان & $\begin{array}{l}\text { Similarly, the girls will also } \\
\text { wash their shyness of the } \\
\text { boys if they are taught with } \\
\text { them }\end{array}$ & $\begin{array}{l}\text { Referring to being less } \\
\text { ashamed (remove shyness) }\end{array}$ \\
\hline 21 & $\begin{array}{c}\text { Not mentioned in Persian } \\
\text { essay }\end{array}$ & 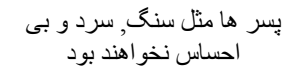 & $\begin{array}{l}\text { Boys won't be like cold } \\
\text { stone }\end{array}$ & $\begin{array}{l}\text { Referring to without } \\
\text { emotions }\end{array}$ \\
\hline 31 & با كوله بارى از تجربيات كذن انتخته، & -- & $\begin{array}{l}\text { They select their wife with } \\
\text { knapsack of past experiences }\end{array}$ & $\begin{array}{l}\text { Referring to the amount of } \\
\text { experience }\end{array}$ \\
\hline 33 & $\begin{array}{c}\text { Not mentioned in Persian } \\
\text { essay }\end{array}$ & سر بهزير & $\begin{array}{l}\text { Girls are always head down } \\
\text { when talking to boys. }\end{array}$ & Referring to girls being shy \\
\hline
\end{tabular}

This last table includes expressions which can bring about the greatest problem in comprehension. As many of these expressions refer to Persian belief or idiom or proverbs, they can create the greatest problems for non-Persian readers. Hence, these transfers in general can be another reason why the Advanced Iranian EFL students' written essays may receive negative scoring on international exams. EFL teachers should also be aware of these transfers and try to assist students to move beyond these types of transfers. Possible reasons for the transfer could be the interference of Persian, the complexity of vocabulary, prepositions and expressions in English, and the students' inadequate knowledge of English (Whalen \& Menard, 1995; Izadi Agha, 2007). Bhela (1999) asserts that "learners will not attain mastery of the target language as long as the process of translation equivalence is in place" (p. 30). He believes that it is only through abandoning translation from L1 to L2 and 
initiating thinking in L2 that the students can master the second language.

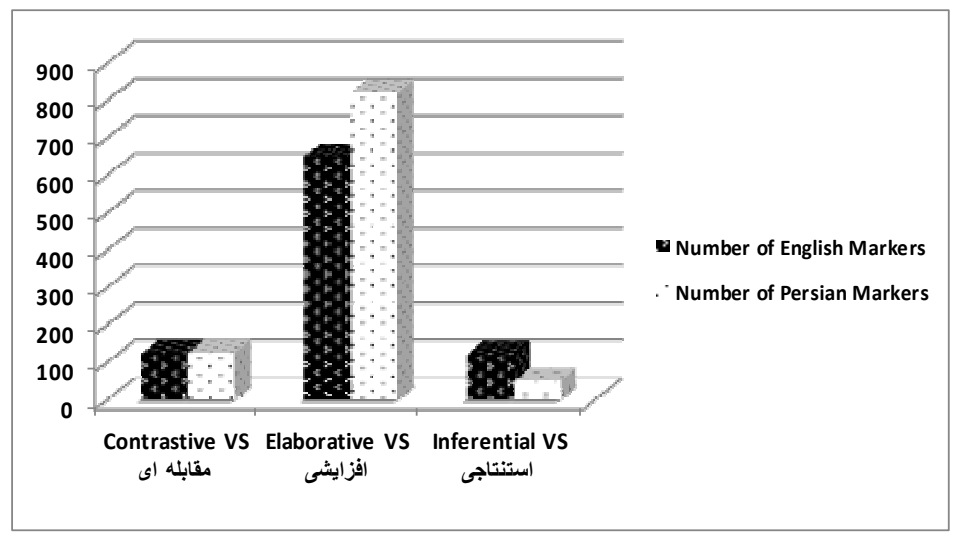

Figure 6. Number of English Markers Vs. Persian Markers

Figures 6 shows the number of English markers as opposed to the Persian ones. In the contrastive marker, the two languages performed very similarly with Persian having $1.31 \%$ more references than English. In elaborative marker, it can be seen that the Persian argumentative essays had more references than the English ones (about 10\% more); and finally the inferential marker seems to be more dominant in the English argumentative essays with almost $8.5 \%$ more references.

In the contrastive markers, the two languages performed similarly. In the Persian elaborative markers, the marker "and" was used most often (629 references as opposed to the 520 references in the English essays) which could explain the relatively longer sentences written in the Persian argumentative essays as compared to the English ones. In the Inferential markers, the English essays used "so" more often (56 references as opposed to the 28 in Persian essays) which could show the participants concern to signal the conclusions and results in their English essays more than the Persian ones.

All in all, the Advanced Iranian EFL students in this study used more explicit discourse markers in their Persian argumentative essays as compared to their English ones. Overall, a total of 103 more references were found in the Persian essays. According to Connor (1996), the higher number of discourse markers assist the readers in trying to make more connections between information coming before and following the discourse markers. It also improves the overall coherence and unity of the writing. Therefore, it seems the students wrote more coherent texts in Persian as compared to the English essays they wrote.

\subsection{Interview}

After the completion of the writing tasks, interviews were conducted with 30 of the Advanced Iranian EFL students. Conducting interviews for the present study assisted the researcher in triangulating the content of what the participants were composing. A set of interview questions were written based on Gosden (1996), Victori (1999), and Buckingham (2008). Each interview was confidential and it was conducted on an individual basis. Each of the interviews, which lasted for about 15-20 minutes, was also transcribed. Here is the most important information obtained from the interviews:

$>\quad$ Most interviewees (22/30) only described a general description of a writing format and not English argumentative writing.

$>\quad 12$ of the interviewees plan their writings in their mother tongue. Most (24/30) interviewees referred to translating from Persian to English during their English writings.

$>\quad$ Half the interviewees did not use outlines.

$>\quad 17$ of interviewees claimed they only used one draft in both their English and Persian writing, but all 
interviewees declared that they made changes in vocabulary and grammar in their English essays.

$>$ All interviewees mentioned they had not learned rhetorical functions and composition styles from Persian composition classes in schools.

$>14$ of the interviewees asserted that the English and Persian argumentative styles of writing were the same.

It is now time to answer each of the research questions.

\subsection{Style Differences between Persian and English Writing According to FCFF (Research Question 1)}

Overall, out of the five contrastive features, two differences were found between the Advanced Iranian EFL students' Persian and English argumentative essays and the first difference found was related to the position of the thesis statement. While the English essays were more inductive (55\%) in nature, the Persian essays were more deductive $(55 \%)$. The second difference is in the number of discourse markers used by the participants. The students used an overall 103 more discourse markers in their Persian essays which should in fact make them more coherent and unified to the reader (Schiffrin, 1987; Connor, 1996; Fraser, 1999; Hutchinson, 2004).

\subsection{Contrastive Features Transferred from Persian to English Writings (Research Question 2)}

1) While English essays are generally more deductive (Kaplan, 1966; Hinds, 1990; Cortazzi and Jin, 1997; Kirkpatrick, 1997; Kubota, 1998; Cho, 1999; Xing, Wang, and Spencer, 2008), the English essays produced by the respondents were inductive in nature. Although students are encouraged to mention their main idea in the first paragraph from the onset of English classes, these Advanced Iranian EFL students did not do so. What is more interesting is that they did not even transfer this from their Persian essay style as they had used a deductive mode for their thesis statements. However, there is a possibility of a backward transfer (Matsuda, 1997; 2001; Cook, 2003; Kecskes, 2008) from English into the Persian essays the students wrote. Meaning, although the students were taught to use a deductive style in their English essays, they ended up transferring this feature to their Persian essays instead of their English ones. The Persian writing manuals generally talk about both styles of deductive and inductive writing without showing preference of one over the other (Horri, 1991; Ghorbaniun, 2004; Solhjoo, 2008).

2) Another difference found was related to number of topic sentences per paragraph (Circularity). According to the findings of the present study, it was determined that the participants used a circular style in which two or more main ideas were used in each paragraph which in turn creates a less comprehensive essay from the readers' perspective. Since it is generally believed that the Persian style of writing is circular (Baleghizadeh and Pashaii, 2010), there is a great possibility that the students have transferred this norm to their English writing. Many of the writing manuals in Persian also warn students against the use of more than one main idea per paragraph (Horri, 1991; Ghorbaniun, 2004; Solhjoo, 2008).

3) The last difference lies in the type of language used in the essays. Many scholars assert that straightforward language is often used in English writing in which the meaning is directly transmitted to the reader (Matalene, 1985; Montano-Harmon, 1991; Connor, 1996; Xing, Wang, \& Spencer, 2008). In the English essays written by the participants, it was discovered that a metaphorical type of language was dominant. Persian relies greatly on the literary patterns used in writing to contribute to the overall beauty of the written text (Dehghanpisheh, 1979; Reid, 1984; Saneh, 2009). Baleghizadeh and Pashaii (2010) also believe that one reason behind the differences between Persian and English rhetoric lies in the fact that Persian is "heavily influenced by poetry so that Iranian prose writers more or less follow the convention of the poetic style" (p. 24). According to this fact, it is apparent that the Advanced Iranian EFL students have been transferring this feature from Persian writing. Questionnaire item 2 also shows that $78 \%$ of the participants support the use of flowery language in their essays. 
Analyzing contrastive features in English and Persian argumentative writing

However, it is noteworthy to mention that during the interview, all the students mentioned they had learned nothing from Persian composition classes in school. As was mentioned earlier, the students are in fact unconsciously transferring the use of flowery language from those Persian composition classes and Persian writing to their English argumentative essays. Also, although the Persian writing manuals advise students to avoid ambiguity while writing (Givi, Hakemi, Shokri, \& Tabatabaee, 2006; Solhjoo, 2008), they do recommend the use of figurative language to add to the beauty of the essays (Derakhshan, 1988; Taherkhani, 1995; Ghorbaniun, 2004; Solhjoo, 2008).

\section{Practical Implications}

The practical implications can be divided into 2 different sections namely- implications for teachers, and implications for students.

\subsection{Implications for Teachers and Professors}

The Importance of Explicit Teaching - Teachers and professors (both Persian Language and EFL) need to focus on presenting the tasks explicitly to the students. The best way to avoid many mistakes such as circularity in writing is for the teachers to directly explain the negative outcomes and help students avoid using it in their writings. Kobuta and Lehner (2004) assert that it is the teachers' responsibility in "making rhetorical differences explicit, raising students' awareness of such differences, and acculturating students through language exercises with concrete models that meet audience expectations" (p. 13). Teachers and professors also need to make the students' aware of the differences between Persian and English rhetorical features. It is important for students to realize that each paragraph in English should only consist of one main idea and that there needs to be a unity all throughout the writing. The students should be warned against the use of literary language which generally makes the comprehension of a text more difficult. It is these details that help the reader to understand the written essay with greater ease.

\subsection{Implications for Students}

The findings of the present study can help EFL students realize that they need to write more objectively in English; and this in turn can aid them to write closer to the standards required by international conventions and the academic community and achieve higher scores for their efforts. One important outcome of the results of the present research is that the Advanced Iranian EFL students who believe they have "individual inadequacies" (Leki, 1991; p. 138) can now be made aware of rhetorical traditions of their native language. These students can finally see that some of the trouble they experience in English writing is actually related to the cultural differences between Persian and English writing. This can be very beneficial regarding boosting the students' motivation to write more effectively.

\subsection{Conclusion and Suggestions for further research}

With the growing number of Iranian students studying abroad, it is necessary to conduct more in depth studies regarding the differences between these students' native language and English. Unfortunately, up to now there is a great gap when it comes to Persian resources regarding the Persian rhetorical cultural norms. There is a specifically wider gap when we get to the structure of Persian argumentative style of writing. There is very scant literature in this regard. This gap needs to be filled with more studies in the future in order to create more effective techniques which are required in order to better communicate in English and be able to share ideas. This study used the five contrastive features framework to analyze the Persian and English argumentative essays of participants. Similar research should be conducted with other modes of writing in order to see whether similar results can be obtained. In doing so, a better and more complete picture of the students' errors could be drawn.

One important issue that went beyond the present study is the cause of errors made by the Advanced Iranian EFL students. Hence, it is highly recommended that future studies be undertaken to improve our understanding 
of the roots of such errors in order to be able to better address the issues. Finally, in the present study, the Advanced Iranian EFL students were initially asked to write in Persian and then in English. Other researchers can consider whether the results would change if the order of language in the given tasks were to be reversed. Also, future researches can be conducted on students at other levels of English proficiency in order to see if similar results can be obtained.

\section{References}

Abdollahzadeh, E. (2010). Undergraduate Iranian EFL learners' use of writing strategies. Writing and Pedagogy, 2(1), 65-90. http://dx.doi.org/10.1558/wap.v2i1.65

Baleghizadeh, S., \& Pashaii, A. (2010). A comparison of English and Farsi rhetoric and its impact on English writing of Iranian students. Studies in Literature and Language, 1(5), 17-27.

Ballard, B., \& Clanchy, J. (1991). Assessment by misconception: Cultural influences and intellectual traditions. In L. Hamp-Lyons (Ed.), Second language writing in academic contexts (pp. 122-134). Norwood, NJ: Ablex Publishing Corporation.

Bhela, B. (1999). Native language interference in learning a second language: Exploratory case studies of native language interference with target language usage. International Education Journal, 1(1), 22-31.

Buckingham, L. (2008). Development of English academic writing competence by Turkish scholars. International Journal of Doctoral Studies, 3, 1-18.

Cho, J. H. (1999). A study of contrastive rhetoric between East Asian and North American cultures as demonstrated through student expository essays from Korea and the United States Unpublished PhD Dissertation Retrieved from http://faculty.fullerton.edu/jcho/dispreface.htm

Connor, U. (1996). Contrastive rhetoric: Cross cultural aspects of second-language writing (3rd ed.). Cambridge: Cambridge University Press. http://dx.doi.org/10.1017/CBO9781139524599

Cook, V. (2003). Introduction: The changing L1 in the L2 User's mind. In V. Cook (Ed.), Effects of the second language on the first (pp. 1-6). Clevedon: Multilingual Matters. http://dx.doi.org/10.1017/cbo9780511806766.003

Cortazzi, M., \& Jin, L. (1997). Communication for learning across cultures. In D. McNamar \& R. Harris (Eds.), Overseas students in higher education: Issues in teaching and learning (pp. 76-90). New York: Routledge.

Daniel, E. L. (2000). The land and people of Iran the history of Iran. Greenwood Press.

Dastmalchian, A., Javidan, M., \& Alam, K. (2001). Effective leadership and culture in Iran: An empirical study. Applied Psychology: An International Review, 50(4), 532-558. http://dx.doi.org/10.1111/1464-0597.00072

Dehghani, Y. (2007). Problems in teaching non-Roman script to English speakers. Paper presented at the AARE 2006 International Education Research Conference. Retrieved from http://www.aare.edu.au/06pap/deh06045.pdf

Dehghanpisheh, E. (1979). Bridging the gap between controlled and free composition: Controlled rhetoric at the upper-intermediate level. TESOL Quarterly, 13(4), 509-519. http://dx.doi.org/10.2307/3586446

Derakhshan, M. (1988). All about the Persian: Spelling, writing, translation (1st ed.). Tehran: Tehran University Publications.

Donahue, T. (2008). Cross-cultural analysis of student writing: Beyond discourses of difference. Written Communication, 25(3), 319-352. http://dx.doi.org/10.1177/0741088308319515

Fakhri, A. (2004). Rhetorical properties of Arabic research article introductions. Journal of Pragmatics, 36, 1119-1138. http://dx.doi.org/10.1016/j.pragma.2003.11.002

Fox, C. M. (2003). Writing across cultures: contrastive rhetoric and a writing center study of one student's journey. University of Rhode Island, Rhode Island.

Fraser, B. (1999). What are discourse markers? Journal of Pragmatics, 31, 931-952. http://dx.doi.org/10.1016/S0378-2166(98)00101-5

Ghorbaniun, H. (2004). Methods of written and spoken presentation (1st ed.). Tehran: Jaam Aria Publishing. 
Analyzing contrastive features in English and Persian argumentative writing

Givi, H. A., Hakemi, E., Shokri, Y., \& Tabatabee, M. A. (2006). Persian language and writing (25th ed.). Tehran: SAMT Publications.

Gosden, H. (1996). Verbal reports of Japanese novices' research writing practices in English. Journal of Second Language Writing, 5(2), 109-128. http://dx.doi.org/10.1016/S1060-3743(96)90021-1

Hafernik, J. J. (1990). Relationships among English writing experience, contrastive rhetoric, and English expository prose of L1 and L2 college writers. University of San Francisco, San Francisco,California.

Hinds, J. (1990). Inductive, deductive, and quasi-inductive: Expository writing in Japanese, Korean, Chinese, and Thai. In U. Connor \& A. M. Johns (Eds.), Coherence in writing: Research and pedagogical perspectives (pp. 87-110). Arlington, VA TESOL.

Horri, A. (1991). Methods of report writing (1st ed.). Tehran: Aryan Publishing.

Hutchinson, B. (2004). Acquiring the meaning of discourse markers. Paper presented at the Proceedings of the 42nd Annual Meeting on Association for Computational Linguistics. http://dx.doi.org/10.3115/1218955.1219042

Izadi Agha, M. (2007). Analysis of written interlanguage of ESL students with Persian backgrounds. Alliant International University, San Diego.

Jalilifar, A. (2008). Discourse markers in composition writings: The case of Iranian learners of English as a foreign language. English Language Teaching, 1(2), 114-122. http://dx.doi.org/10.5539/elt.v1n2p114

Kaplan, R. B. (1966). Cultural thought patterns in inter-cultural education. Language and Learning: A Journal of Applied Linguistics, 16(1/2), 1-20. http://dx.doi.org/10.1111/j.1467-1770.1966.tb00804.x

Kecskes, I. (2008). The effect of the second language on the first language. Babylonia,The Swiss Journal of Language Learning, 2(8), 30-34.

Kirkpatrick, A. (1995). Chinese rhetoric: Methods of argument. Multilingua, 14(3), 271-295. http://dx.doi.org/10.1515/mult.1995.14.3.271

Kirkpatrick, A. (1997). Traditional Chinese text structures and their influence on the Writing in Chinese and English of contemporary mainland Chinese students. Journal of Second Language Writing, 6(3), 223-244. http://dx.doi.org/10.1016/S1060-3743(97)90013-8

Kobayashi, H., \& Rinnert, C. (2008). Task response and text construction across L1 and L2 writing. Journal of Second Language Writing, 17, 7-29. http://dx.doi.org/10.1016/j.jslw.2007.08.004

Kubota, R. (1998). An investigation of L1-L2 transfer in writing among Japanese university students: Implications for contrastive rhetoric. Journal of Second Language Writing, 7(1), 69-100. http://dx.doi.org/10.1016/S1060-3743(98)90006-6

Kubota, R., \& Lehner, A. (2004). Toward critical contrastive rhetoric. Journal of Second Language Writing, 13(1), 7-27. http://dx.doi.org/10.1016/j.jslw.2004.04.003

Leki, I. (1991). Twenty-five years of contrastive rhetoric: Text analysis and writing pedagogies. TESOL Quarterly, 25(1), 123-143. http://dx.doi.org/10.2307/3587031

Leki, I., \& Carson, J. G. (1994). Students' perceptions of EAP writing instruction and writing needs across the disciplines. TESOL Quarterly, 28(1), 81-101. http://dx.doi.org/10.2307/3587199

Liu, Y., \& You, X. (2008). Negotiating into academic discourses: Taiwanese and U.S. college students in research writing. International Journal of English Studies, 8(2), 152-172.

Lux, P. A. (1991). Discourse styles of Anglo and Latin American college student writers. Arizona State University, Arizona.

Matalene, C. (1985). Contrastive rhetoric: An American writing teacher in China. College English, 47(8), 789-808. http://dx.doi.org/10.2307/376613

Matsuda, P. K. (1997). Contrastive rhetoric in context: A dynamic model of L2 writing. Journal of Second Language Writing, 6(1), 45-60. http://dx.doi.org/10.1016/S1060-3743(97)90005-9

Matsuda, P. K. (2001). On the origin of contrastive rhetoric: A response to H. G. Ying. International Journal of Applied Linguistics, 11(2), 257-260. http://dx.doi.org/10.1111/1473-4192.00017

Montaño-Harmon, M. R. (1991). Discourse features of written Mexican Spanish: Current research in contrastive rhetoric and its implications. Hispania, 72(4), 417-425. http://dx.doi.org/10.2307/344852

Raimes, A. (1983). Techniques in teaching writing: Oxford University Press. 
Kamyabi Gol, A.

Reid, J. M. (1984). ESL composition: The linear product of American thought. College Composition and Communication, 35(4), 449-452. http://dx.doi.org/10.2307/357797

Reid, J. M. (1988). Quantitative differences in English prose written by Arabic, Chinese, Spanish, and English students. Colorado State University, Fort Collins, Colorado.

Robitaille, J., \& Connelly, R. (2007). Writer's resources: From paragraph to essay (2nd ed.). Boston, MA: Wadsworth.

Rooholamini, S. D. (1986). A cultural manual in English as a foreign language for advanced students from Iran. Fairleigh Dickinson University, New Jersey.

Samiee, A. (2008). Writing and editing (9th ed.). Tehran: Samt Publications.

Saneh, N. A. (2009). Intercultural rhetoric in higher education: The case of Iranian students' textual practices in North American graduate schools. University of Ottawa, Ottawa.

Schiffrin, D. (1987). Discourse markers. Cambridge: Cambridge University Press. http://dx.doi.org/10.1017/CBO9780511611841

Schneider, M. L., \& Fujishima, N. K. (1995). When practice doesn't make perfect: The case of a graduate ESL student. In D. Belcher \& G. Braine (Eds.), Academic writing in a second language: Essays on research and pedagogy (pp. 231-265). Norwood, NJ: Ablex Publishing Corporation.

Siepmann, D. (2006). Academic writing and culture: An overview of differences between English, French and German. Meta: Translators' Journal, 51(1), 131-150. http://dx.doi.org/10.7202/012998ar

Solhjoo, A. (2008). Remarks on editing. Tehran: Nashr-e-markaz Publications.

Strain, J. E. (1971). English language instruction in Iran. English Record, 21(4), 31-38.

Taherkhani, A. (1995). The correct way to write (1st ed.). Tehran: Negin Publications.

Victori, M. (1999). An analysis of writing knowledge in EFL composing: a case study of two effective and two less effective writers. System, 27(4), 537-555. http://dx.doi.org/10.1016/S0346-251X(99)00049-4

Whalen, K., \& Menrad, N. (1995). L1 and L2 writers' strategic and linguistic knowledge: A model of multiple-level discourse processing. Language and Learning, 45(3), 381-418. http://dx.doi.org/10.1111/j.1467-1770.1995.tb00447.x

Wong, S. D. (1992). Contrastive rhetoric: An exploration of proverbial references in Chinese student L1 and L2 writing. Journal of Intensive English Studies, 6, 71-90.

Xing, M., Wang, J., \& Spencer, K. (2008). Raising students' awareness of cross-cultural contrastive rhetoric in English writing via an e-learning course. Language Learning \& Technology, 12(3), 71-93.

Zarei, G. R., \& Mansoori, S. (2007). Metadiscourse in academic prose: A contrastive analysis of English and Persian research articles. The Asian ESP Journal, 3(2), 24-40.

Zia Houseini, S. M., \& Derakhshan, K. (2006). Transfer of first language of foreign language writing: A contrastive rhetoric study of English and Farsi. Quarterly Journal of Humanities Al-Zahra University, 16(58), 75-91. 